\title{
The significance of research into the Roma ethnic identity. Proposals for theories, methods, and research organization based on the own scientific experiences
}

\begin{abstract}
The article is aimed at drawing attention to the research motifs explored by the author in his studies and, first of all, at raising questions about the sense of research into the Romani identity. An attempt is made here both to suggest some theories and methods which can be useful in identity studies and to signal the difficulties in carrying such research out. The major subject matter of the suggested research projects should address the problems of the Romani identity and culture, this ethnic group's participation in education, and their specific social and professional activity. What seems to be justified (after a reliable diagnosis of the needs, problems, prospects and possible solutions) is the unceasing need for designing programmes, projects and local policies which address the Roma and which come into being with their participation. However, the activities conducted so far should be subjected to an in-depth analysis and evaluation, also in regard to the specificity of Roma communities from various groups and countries. This might help to indicate the elements of their identity, as well as the level of joint participation in the context of the still incomplete integration with culturally dominating majorities.
\end{abstract}

Keywords: Roma, identity, ethnicity, education, integration, interculturalism, theory, methods

\section{Introduction}

For many years, the problems of national and ethnic minorities with special focus on the situation of Romani people in Poland and other countries of Central Europe have been the main object of my scientific explorations. Therefore, it seems useful to share my experience and indicate the usefulness of some theories, the main problems with the organization of studies, as well as some fields worth further research. My scientific interests have developed while preparing a lot of research compliant with the pedagogical area 
but also involving an interdisciplinary approach, field studies, often clearly non-positivist participatory action research. In Poland, the publications of educationalists successfully undertaking participatory action research have become available in the recent years as well (Červinková, 2012; Gołębniak, Červinková, 2010, 2013). There are more studies by foreign authors available, among others: Khanlou (2005), Oden, Hernandez, Hidalgo (2010), Levanon (2011). This subject matter is evidently connected both with my scientific background and with the above mentioned social activity. As regards my current investigations, the intention is to make an attempt to conceptualize and describe the social involvement for the Romani community and, first of all, the activity of the Roma themselves, in the context of their participation in actions for and with their own environment. Thus, the community of educators may become more aware of the recently undertaken (with growing frequency) action research in fieldwork, additionally justified by joint participation. What seems remarkable is also its emancipatory character. Field action research is particularly suitable for finding out the attitudes, behaviour patterns and social phenomena which can be understood only in the natural environment of the Romani, as opposed to an experiment or survey organized in partially artificial conditions. Field research is conducted in a place and in certain time, when observable events often happen. My studies have been carried out as parts of scholarships, internships, scientific and social projects, analyses and expert opinions (commissioned by local authorities and central government administration), grants and university statutory research. So far, In Polish pedagogy there have not been many research attempts at studying the social, cultural and educational functioning of children and adults of Romani ethnic minority in the conditions of Europe's cultural diversity. The previous state of knowledge in this respect, presented mainly on the grounds of ethnology, history or sociology, is comprised in the scope of intercultural pedagogy and comparative pedagogy.

\section{Contexts, cognitive goals and scientific research}

In reference to the existing stereotypes about the economic activity of Romani people, their social participation, education of Romani children and youth, and in the atmosphere of no understanding of their otherness, it seems justified to aim at designing research into the specificity of this cultural otherness. This otherness (depending on ethnic identity) consists in a different way of looking at formal law, in a different approach to education of children, 
social and vocational activity of the Romani and in incomplete integration with the culturally dominating community in their residence country. My attempt to prepare for such research effort starts with raising the initial question concerning the need and sense of exploring the significance of conducting field research into the identity of an ethnic group. The adopted research procedure - participatory intervention research - enables a transformation of social reality and the use of research results in practice. The qualitative-quantitative approach was applied: participatory observation, document analysis (research results, publications, legal acts, programmes, projects), interviews with representatives of the Romani community, various studies and expert reports (Kwadrans, 2013, 2017). In regard to the specificity of the research subject and due to undertaking some attempts to blur the boundaries between the object and the subject of the research, one may point to a particular kind of motivation behind such attempts. On the one hand - it is by no means an effort and scientific challenge, and - on the other hand - mere curiosity, a cognitive incentive. Therefore, a multicontextual motivation for the research can be indicated, which I have often applied: cognitive motivation, the community-related thread as well as the political and social one altogether.

Such an interdisciplinary approach to the problem incorporates sociological, politological and primarily pedagogical approaches. On the grounds of these disciplines of science, there are a few essential notions: ethnic identity, behaviour norms and patterns, social (mis)fitting, culture, education, integration, joint participation. The interdisciplinary approach is also aimed to determine differences in defining integration or participation more often than joint participation, an attitude to education, social and vocational activity by culturally diverse groups - here in the case of Romani people. Some attempt have been made as well to indicate alternative forms of social fitting of the Roma. The choice of problems is also determined by other factors, such as the still difficult social and legal situation and incomplete integration of the Romani in Europe and the continuously valid questions of the need for change. The current scientific goals include completing my previously attempted studies of the problems of Romani education as well as extending them by including other above-mentioned subjects. What should be emphasized is that, apart from ethnographic, sociological or politological works, there are still very few pedagogical studies on Romani ethnic minority and its social participation. Thus, the scientific goals should include a description, diagnosis, analysis and interpretation of the situation of the Romani in the context of their integration in numerous areas; a critical presentation of the 
pursued actions addressing this group by international, government and selfgovernment institutions as well as non-government organisations (their aims and methods), but - first of all - an in-depth study of their ethnic identity.

\section{The course of the research}

The proposed research involves representatives of Romani groups in a few countries of Central Europe. What can be recommended for the purpose of this research is not the use of interview questionnaires (because some respondents might be illiterate) but of free interview. It seems valuable to enrich the materials with Romani leaders' opinions. First of all, however, the document analysis should be conducted of scholarly papers, official documents in the form of programmes, projects, or local policies. So far, the most effective action research has been conducted through participation in numerous projects aimed at Romani communities in those countries. Its aim has been to identify the attitude towards the processes of integration (assimilation). The conclusions drawn from the so far conducted studies have formed the basis for raising the main research problem which consists in the question: Whether and to what extent may the problems with Romani integration result from their cultural otherness contained in the elements of their ethnic identity, culture, ways of adapting to the functioning in the society of the culturally dominating majority?

The theoretical goals have been focused on organizing and collecting the knowledge on: the characteristics of the situation of the Romani, their culture, ethnic identity, social and cultural integration, adaptive strategies, specificity of their social and cultural capital, intercultural education, social change, transformation, European integration, globalisation. I have also made attempts to describe the Romani participation in the culture and education of majority societies, the execution of educational duty and their participation in education. It seems to be very important to emphasize the theme of education. In the context of research, in such studies it is obligatory to include the presentation or description of the Romani community's actions along with their evaluation.

Among other things, some attempts have been made in my studies to depict otherness in relation to education of Romani people in their residence country. Those studies have grasped the way the Romani perceive education and educational duty. What has been also presented are the relations between the Romani sense of identity and their attitude to education and their 
participation in it. Numerous foreign internships and study visits in Poland have allowed me to collect materials through library study (of programmes, projects, specific legal regulations, documents of institutions dedicated to work for the Romani, associations, foundations). Interviews with Romani leaders and people involved in work for the Romani have allowed me to enrich the research material.

\section{Characteristics of the studied group's ethnic identity - the theoretical context}

The main subject matter of the study is Romani identity as the foundation for the functioning of the Roma in the contemporary world as well as a determinant of their attitude to the culturally dominating societies, integration programmes, education system, and labour market. It should be stressed here that the Romani identity is one of the key notional categories. My intention is to indicate the theories that are useful in the interpretation of research results, as well as to indicate their organization and methodological premises. My own studies constitute the base here for sharing my experience which may help in designing research projects in the future. In my written works, I consistently try to use the term "Romani", by which I mean not its ethnic sense but the political one. Despite certain negative language connotations that the term "Gypsies" convey, it is still used for the reasons of historical or merit-related correctness. Keeping in mind the diversity in the described community, "Romani" is used here in its political sense, which embraces all Roma groups. I am also aware that some of them do not use this ethnonym (Mirga and Mróz, 1994, p. 266-267; Kapralski, 2012, p. 7 and 77-135).

Gypsies/Romani - according to an American anthropologist and gypsologist Matt Salo (1979, pp. 73-96) - differ in terms of six basic criteria which largely influence different functioning of this ethnic group in many spheres of social life (Mirga, Mróz, 1994, pp. 267-269). To the present day, this theory has been used in descriptions and analyses pertaining to the Romani identity. The theoretical concept which allows researchers to systematize the determinants of Romani identity (Kwadrans, 2015) and has been used in the description of its related areas is Tadeusz Lewowicki's Theory of Identity Behaviours (Polish abbreviation: TZT; Lewowicki, 2001, pp. 161-164). Especially in comparison with the majority group, as Lewowicki claims, the concentration on a chosen minority group distorts the reality and disrupts finding out some more general regularities, circumstances, relations (Lewowicki, 1995, p. 20). 
The Romani identity is still being transformed and is a subject to influences triggered off by social and civilizational changes. It tends to be enhanced by some elements drawn from other cultures (e.g. through education and personal contacts with members of other communities, media, the Internet) and also diminished to give way to some new, unknown areas. School curricula are a subject to modification which depends on the scientific and technological progress. Thus, science and politics should be linked with the shaping of identity. Communion in its traditional understanding is replaced by new institutions or organizations, very often impersonal ones (media, the Internet). Moreover, social and cultural identity of the Romani is undergoing transformation, which manifests itself in their increasing participation in the social, economic and political life of their residence countries. They are adapting more and more efficiently to constant changes, which is by no means irrelevant to their identity. What often occurs among the Romani is the doubling or tripling of their identity. While interviewing the Romani, I have dealt with many declarations of multidimensional identity. Jerzy Nikitorowicz accepts the possibility of the existence of many identity dimensions. In one of his books, the author introduces the Theory of Multirange and Multidimensional Identity (Polish abbreviation: TWiWT), the sense of which is the individual's consciousness in the process of developing a complex, multirange and multidimensional identity. It is treated as a creative effort of the subject who reduces tensions and contradictions between constant, heritable elements, resulting from being socially rooted in family and local community (such as the identification with significant individuals and groups, indigenous symbols and values) and variable, acquired elements, resulting from the reactions and interactions, social roles and positions as well as experiences of participation in the multicultural world (Nikitorowicz, 2017, p. 347).

A mechanism which controls the cohesion of Romani groups is the strongly developed inner social control in the form of a code of norms and an institution of "specific jurisprudence" (the rule of mageripen, romanipen, manusipen) (Courthiade, 2008, pp. 13-32; Marushiakova and Popov, 2008, pp. 13-77). While conducting analyses of Romani identity, these institutions cannot be forgotten. What might help here are some sociological theories e.g. of social control (Siemaszko, 1993). It is meaningful that there are still so few emancipated Romani and that they are often rejected by the society. Among the Romani, the phenomenon is quite frequent of unsymmetrical social bonds (Ossowski, 1967, pp. 137-173). They would like to belong to a given country's dominant majority and they are convinced that they are 
entitled to it and, at the same time, they feel rejected by this majority. Thus, it may be stated that Romani's subjective otherness is insignificant, contrary to the reflected otherness. Therefore, there are problems with integration in the scope projected by the cultural majority.

\section{Characteristics of the research into the Romani ethnic group - methodological dilemmas}

The specificity of the research necessitates finding answers to the following questions: Who are Gypsies/Romani? Should gypsology or romalogy be mentioned? Are the researchers conducting social studies on Romani ethnic identity gypsologists/romalogists? Are these terms legitimate? Gypsology is a branch of ethnology and linguistics dealing with the study of the history, culture and language of Gypsies/Romani. Obviously, some interest in this community has accompanied it since their arrival in Europe or the beginning of their journey. However, the development of philological, historical and ethnographical studies must date back to the late $18^{\text {th }}$ century. Nowadays, also sociology, pedagogy and other humanistic or social studies are involved in the research on the history, culture and situation of Gypsies/Romani. The name gyspology was adopted by the non-Roma and, therefore, the reference to the exoethnonym Gypsies should not come as a surprise. Currently, a discussion is also taking place on the very name gypsology, because in the institutional sphere there is the term romalogy, derived from the endoethnonym Roma. Some gypsologists divide the field into the traditional and contemporary approach to the Romani community as one extensive group and put emphasis on the awareness of group diversity and lack of the sense of community.

Romalogical studies are usually of an interdisciplinary character and are conducted with the use of various perspectives, e.g. of cultural anthropology, sociology, theory of culture, as well as philosophy or history, and more recently also of pedagogy. Research into the Romani provides factual evidence and is more and more often referred to as a separate field - romalogy. It is not comprised in the traditional status of science and is characterized by different approaches located in separate paradigms, for example in what Romani identity is and how it is to be studied. Thus, assuming that the Romani are a group that is internally highly diversified, it is not possible to conduct research aimed at making judgements about Romani people (Kapralski, 2012).

Yet, the most frequently undertaken studies on Gypsies/Romani are scientific efforts of linguists, historians, ethnographers, sociologists and less 
often of psychologists or educationalists. What seems significant is that the researchers are usually non-Romani.

The most common difficulties in carrying out research are those resulting from the specificity of a group (punitive structures), lack of possibility of joining the group, problems of cultural differences, language problems, poor communicative and technological competences, passing on from individual to collective interviews, a disturbed relation between a researcher and the researched, mutual stereotypes, subjectivism, ethical implications, different levels of intercultural competences of the researcher and the researched, lack of clearly specified or abstract purposes (this is clearly seen in many projects implemented within EU programmes and in the evaluation of some studies after their completion), problems of forced utility of research or its only descriptive character.

It would be recommended to ask the following questions concerning the need to carry out research into Roma, especially into their ethnic identity: Is there any need? Are researchers authorised? How should they investigate? For the reason of the above-mentioned characteristics of the group and a definite need to depart from quantifiable analysis, it would be necessary to conduct fieldwork, ethnographic studies, action research, and to refer to a well-grounded theory.

\section{Conclusions}

The presented study was aimed not so much at triggering a discussion on the need for research among the Romani community but rather at enabling the indication of its directions. Obviously, this required reviewing the key notional categories. The contents of this article might help in choosing most useful theories, methods and techniques of data collection and of making descriptions or analyses. Both the theoretical considerations and the experience of my own research make it possible to confirm that the key category in such scientific exploration is the notion of the Romani ethnic identity. Applying a different paradigm which ignores identity analyses seems erroneous and may lead only to unjustifiable conclusions or, very often, to wrong assumptions. Therefore, the studies on the Romani community - regardless of their aims and assumptions - should be designed with full awareness of the research significance of Romani identity. It seems recommended that the questions and problems raised in such studies should be formulated also in regard to this issue. The interpretation of research results, the scientific 
procedure, the choice of methods, techniques and tools ought to take the category of ethnic identity into account as well.

\section{Bibliography}

Courthiade, M. 2008. O romskim sądzie obyczajowym. Studia Romologica. 1, pp. 13-32.

Červinková, H. 2012. Badania w działaniu i zaangażowana antropologia edukacyjna. Teraźniejszość - Człowiek - Edukacja. 1 (57), pp. 7-17.

Gołębniak, B.D. and Červinková, H. eds. 2010. Badania w działaniu: pedagogika i antropologia zaangażowane. Wrocław: Wydawnictwo Naukowe DSW, pp. 7-17.

Gołębniak, B.D. and Červinková H. eds. 2013. Edukacyjne badania w dziataniu. Warszawa: Wydawnictwo Naukowe Scholar.

Hancock, I. 1991. The East European Roots of Romani Nationalism. In: Crowe, D. and Kolsti, J. eds. The Gypsies of Eastern Europe. Armonk - London - New York: M.E.Sharpe, Inc., pp. 133-150.

Kapralski, S. 2012. Naród z popiołów. Pamięć zagłady a tożsamość Romów. Warszawa: Wydawnictwo Naukowe Scholar.

Khanlou, N. 2005. Participatory action research: considerations for ethical review. Social Science \& Medicine. 60 (10), pp. 2333-2340.

Kwadrans, Ł. 2013. Prawo jako zewnętrzny i wewnętrzny czynnik warunkujący zachowanie w społeczności romskiej - potrzeba podjęcia badań. Studia Romologica. 6, pp. 127-133.

Kwadrans, Ł. 2017. Roma Identity, Integration and Education. Comparative Research. Culture E Education. 4 (118), pp. 60-73.

Kwadrans, Ł. 2015. (Sinti, Kale, Manus, Lovari, Kelderash...) - Gypsies - Romani. From ethnic identity to national or multidimensional identity? In: Kyuchukov, H., Lewowicki, T. and Ogrodzka-Mazur, E. eds. Intercultural education: concepts, practice, problems. Munich: Lincom Academic Publishers, pp. 71-83.

Lewowicki, T. 1995. O badaniach społeczności pogranicza-od parcjalnych opisów ku elementom teorii zachowań tożsamościowych. In: Nikitorowicz, J. ed. Edukacja międzykulturowa. W kręgu potrzeb, oczekiwań i stereotypów. Białystok: Wydawnictwo Uniwersyteckie „Trans Humana”, pp. 13-27.

Lewowicki, T. 2001. Szkic do teorii zachowań tożsamościowych. In: Lewowicki, T. and Ogrodzka-Mazur, E. eds. W poszukiwaniu teorii przydat- 
nych w badaniach międzykulturowych. Cieszyn: Uniwersytet Śląski - Filia w Cieszynie, pp. 161-164.

Levanon, A. 2011. Ethnic social capital: Individual and group level sources and their economic consequences. Social Science Research. 1 (40), pp. 77$-86$.

Marushiakova, E. and Popov, V. 2008. Sąd cygański w Europie Wschodniej. Studia Romologica. 1, pp. 13-77.

Mirga, A. and Mróz, L. 1994. Cyganie. Odmienność i nietolerancja. Warszawa: Wydawnictwo Naukowe PWN.

Nikitorowicz, J. 2017. Etnopedagogika w kontekście wielokulturowości i nieustannie kształtującej się tożsamości. Kraków: Oficyna Wydawnicza „Impuls".

Oden, K., Hernandez, B. and Hidalgo, M. 2010. Payoffs of participatory action research: racial and ethnic minorities with disabilities reflect on their research experiences. Routledge Community Development. 41 (1), pp. 21-31 .

Ossowski, S. 1967. Wielogłowy lewiatan a grupa społeczna. O perypetiach pojęciowych w socjologii. In: Ossowski, S. Dzieła. Vol. IV. Warszawa: Wydawnictwo Naukowe PWN, pp. 137-173.

Salo, M. 1979. Gypsy Ethnicity: implications of Native Categories and Interaction for Ethnic Classification. Ethnicity. 6, pp. 73-96.

Siemaszko, A. 1994. Granice tolerancji: o teoriach zachowań dewiacyjnych. Warszawa: PWN. 